\title{
Sedimentation of the Lower Cretaceous Xiagou Formation and its response to regional tectonics in the Qingxi Sag, Jiuquan Basin, NW China
}

\author{
Si Chen ${ }^{\mathrm{a}, \mathrm{b}}$, Hua Wang ${ }^{\mathrm{a}, *}$, Jun Wei ${ }^{\mathrm{c}}$, Zhenyu Lv $^{\mathrm{d}}$, Huajun Gan ${ }^{\mathrm{a}}$, Siding Jin ${ }^{\mathrm{a}}$ \\ ${ }^{a}$ Key Laboratory of Tectonics and Petroleum Resources, MOE, China University of Geosciences, Wuhan 430074, China \\ backson School of Geosciences, The University of Texas at Austin, 78712, USA \\ ${ }^{c}$ PetroChina Yumen Oilfield Company, Yumen 735200, China \\ ${ }^{\mathrm{d}}$ Tianjin Branch of CNOOC Ltd., Tianjin 300452, China
}

\section{A R T I C L E I N F O}

\section{Article history:}

Received 24 May 2013

Accepted in revised form 11 November 2013

Available online 11 December 2013

\section{Keywords:}

Jiuquan Basin

Qingxi Sag

Xiagou Formation

Sediment infill

Tectonic evolution

\begin{abstract}
A B S T R A C T
Under the constraint of an isochronous sequence stratigraphic framework, sediment infill of the Xiagou Formation reflects the overall control of dynamic tectonic movements and episodic sedimentations in the Qingxi Sag. Structure reactivity during post-depositional processes could cause stratigraphic variations in longitudinal time and lateral space. This study documents sediment infill features and their response to the tectonic evolutions of the Qingxi Sag. The data sets include comparison of cores, well drilling, 3D seismic, inter-well correlation, wave impedance inversion profiles, original strata recovery data, sedimentary facies spatial evolution and their superimposition with paleogeomorphology.

The Jiuquan Basin is a Mesozoic-Cenozoic superposition basin comprising an early rifting graben phase and a later compression phase. Since the Early Cretaceous, the basin has undergone four major tectonic episodes: 1) extension during the Early Cretaceous, 2) tectonic inversion caused by northwest-southeast contraction from the Late Cretaceous to the Paleocene, 3) weak extension from the Eocene to the Miocene and 4) contraction from the Miocene to the present. Therefore, the Jiuquan Basin is the product of taphrogenic, collisional and shearing movements.

Seismic interpretations of sequence and maximum flooding surface divide the Xiagou Formation into three third order sequences: $\mathrm{SQK} 1 \mathrm{~g}_{0}, \mathrm{SQK} 1 \mathrm{~g}_{1}$ and $\mathrm{SQK} 1 \mathrm{~g}_{2+3}$. Five sedimentary facies associations are identified: the shoreland plain, fan delta dominated sedimentary systems, turbidite deposits, shallow lakes and half-deep lake systems. From $\mathrm{K} \mathrm{g}_{0}$ to $\mathrm{K} \mathrm{g}_{2+3}$, decreased sandstone percentages in three fan delta areas indicate a continuously transgressive process, which shows the transition from proximal to distal sites in most statistic wells and an obvious decrease of fan delta scales. The northeast-southwest faults control the lakeward distributions of delta fronts and turbidite fans.

The correspondence of sedimentary infill and its response to tectonic movements have been demonstrated in the Qingxi Sag. The more active eastern part of the northeastern boundary fault has an important influence on the northeastward migration of depocenters in the Xiagou Formation. The topography developed continuously from $\mathrm{K} \mathrm{g}_{0}$ to $\mathrm{K}_{1} \mathrm{~g}_{2+3}$, but the diminished subsidence indicates the dominant geological process varying from intense fault rifting in an early period to relatively gentle and overall subsidence in a later period during the Early Cretaceous.
\end{abstract}

(C) 2013 Elsevier Ltd. All rights reserved.

\section{Introduction}

Sediment supplies and dynamic processes during depositional stages, reconstructions during post-depositional processes and a geological sand body's responses to multiple factors, such as

\footnotetext{
* Corresponding author.

E-mail address: sichen720@hotmail.com (S. Chen).
}

tectonic movements and fault activities, should be studied in basin analysis (Liu, 1986). Basin tectonic movements directly affect the sedimentary infill and hydrocarbon formation. Under the constraint of a comprehensive and elaborate isochronous sequence stratigraphic framework, the sediment infill and hydrocarbon reservoir features of the Xiagou Formation reflect the overall control of dynamic tectonic movements and episodic sedimentations in the Qingxi Sag. Changes caused by structural reactivation in postdepositional processes could cause stratigraphic variations of the 
Xiagou Formation in longitudinal time and lateral space. Lin (2009) studied the sequence stratigraphy, infill architecture and response process of sedimentary basins, which indicate that the formation relationship between the sequence series and multi-stage basin tectonic movements is the key factor for sedimentary evolution and petroleum accommodation in tectonic basins or large superimposed basins (Lin, 2009). Ren et al. 1999 studied the episodic filling evolution of the Wuliyasitai faulted basin in the Erlian Basin, which indicates that episodic tectonic movement is the main control factor to develop higher order sequences and has a response relationship with the sedimentary filling of the basin (Ren et al., 1999). Consequently, the sediment infill and its response to tectonic evolution are significant for petroleum exploration. Because it is the site of the oldest oilfield in China, many previous studies have been conducted on the structural characteristics, tectonic evolution, and petroleum reservoir prospecting of the Qingxi Sag in the Jiuquan Basin (Li et al., 2006; Li et al., 2002; Pan et al., 2006; Ren et al., 2000b; Sun et al., 2006; Wang et al., 2005b; Wang and Coward, 1993). However, there are few studies, if any, about detailed sedimentary system analysis, the longitudinal evolution process of sediment infill, and their relationship with the tectonic influence of the Lower Cretaceous in the Qingxi Sag, Jiuquan Basin. Thus, the main goals of this paper were to document sediment infill features and their responses to tectonic evolution under an isochronous sequence stratigraphic framework using an integrated study of drilling and seismic data, sedimentary facies, structural analyses and cross-section reconstructions.

This paper is presented as follows: first, the regional background, tectonic history and petroleum system are introduced in the geological setting section. Then, the sedimentary infill and sequence stratigraphy framework are described and analyzed based on the comprehensive comparison of core, well drilling, seismic, inter-well correlation and wave impedance inversion profiles, as well as the plane sedimentary face distribution. Finally, the sedimentation responses to the tectonic activities and the control of tectonic evolution over the sedimentary infill are discussed, including the boundary fault activity influences, strata depocenter migration, tectonic evolution profiles that are based on

A

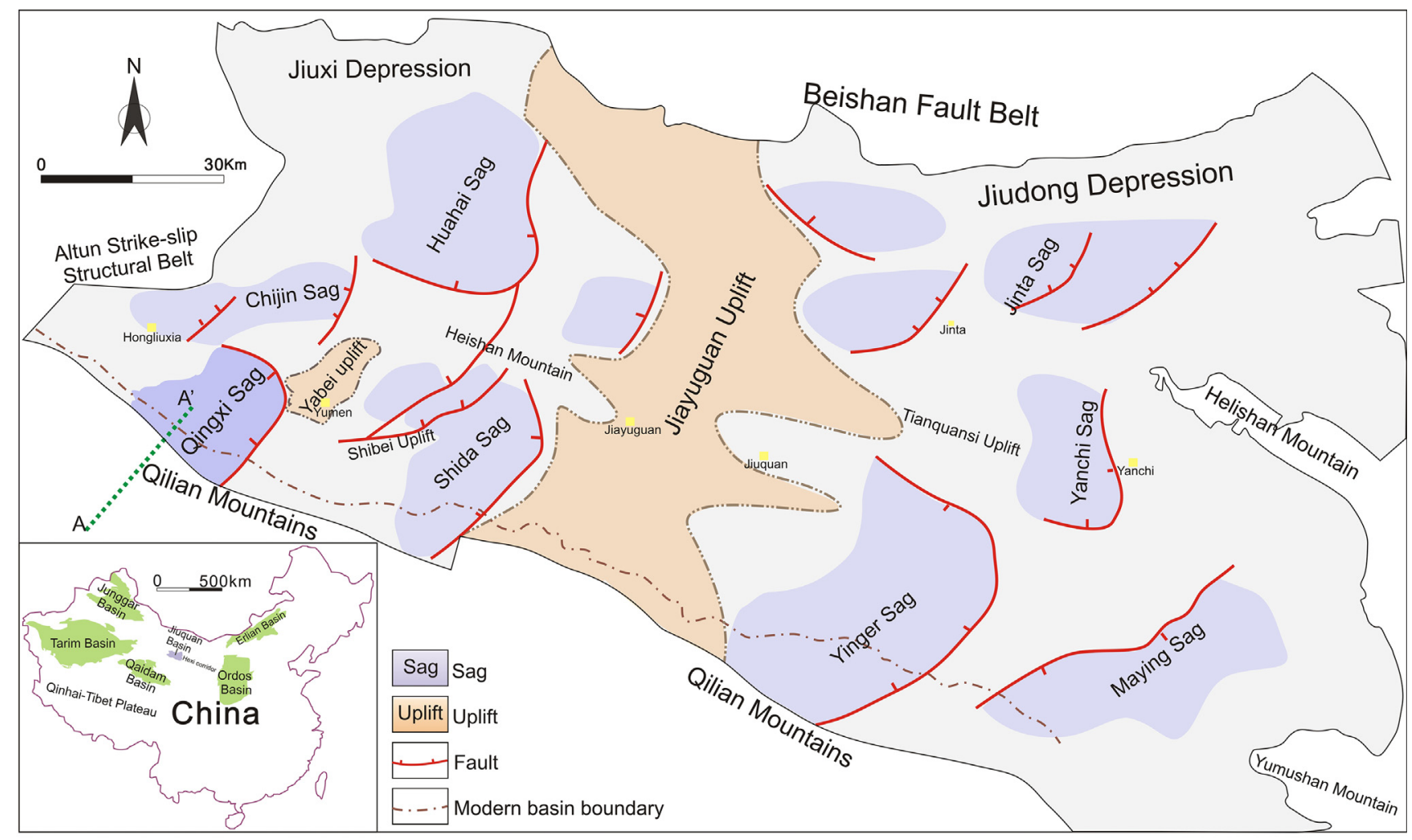

B

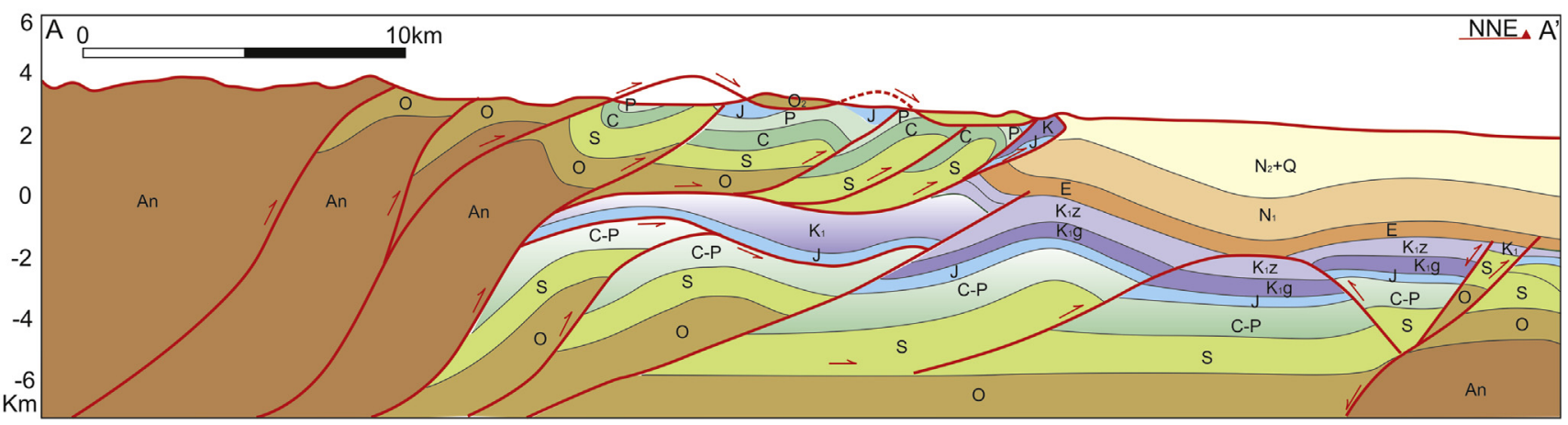

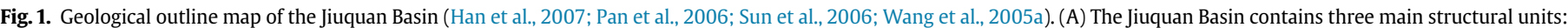

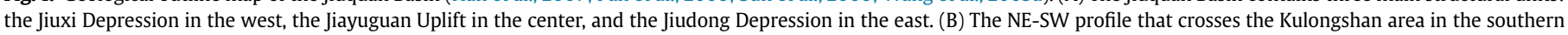
margin of the Jiuquan Basin shows the imbricate north Qilian thrust system (Chen et al., 2006; Han et al., 2007). See dotted line AA' in A to locate this survey line. 

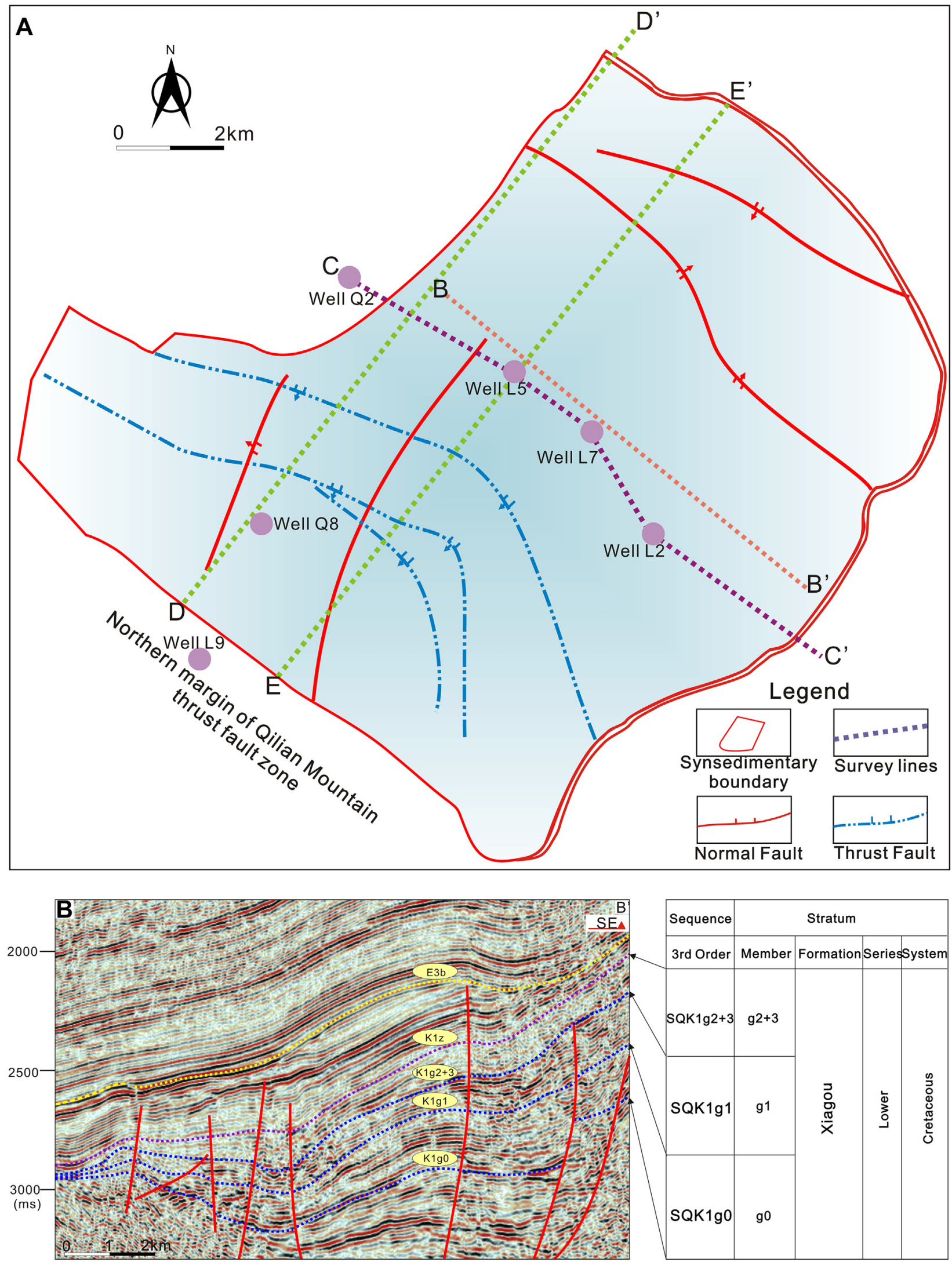

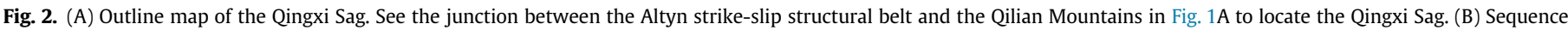

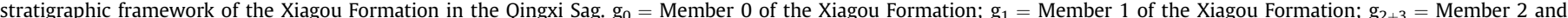
member 3 of the Xiagou Formation. See dotted line $\mathrm{BB}^{\prime}$ in A to locate this survey line. 
original strata recovery data and detailed research of longitudinal sedimentary facies evolution and their superimposition with paleogeomorphology.

\section{Geological setting}

\subsection{Regional geologic background of the Jiuquan Basin}

The Jiuquan Basin is on the northern edge of the Qilian orogeny belt (Fig. 1A), which is bordered by the Altyn Tagh tectonic belt to the northwest and the Beishan tectonic belt to the northeast. It is a petroliferous basin on the western end of the Hexi Corridor Basin group, and north of the Qinghai-Tibet Plateau, with an area of 22,000 km² (Li et al., 2006; Pan et al., 2006; Shi et al., 2001; Wang et al., 2005a; Wang et al., 2005b; Wang et al., 2008; Wen et al., 2007; Zhu et al., 2006). From west to east, the Jiuquan Basin is divided into three first-order tectonic units (Yang et al., 2002): the Jiuxi Depression in the west, the Jiayuguan Uplift in the center, and the Jiudong Depression in the east (Fig. 1) (Vincent and Allen, 1999; Wang et al., 2005b). These first-order units can be further divided into their component tectonic sub-units. For example, the Jiuxi Depression comprises the Huahai-Shida Sag, the Chijin Sag, and the Qingxi Sag (Fig. 2), and the Jiudong Depression comprises the Yinger Sag, Maying Sag, Yanchi Sag, and Jinta Sag (Wang et al., 2005a; Wen et al., 2007).

Most secondary sedimentary sags in the Jiuquan Basin represent a NE trending distribution, including the Huahai Sag, Shida Sag, Jinta Sag, Yinger Sag, and Maying Sag (Fig. 1A). They have undergone a similar evolution giving them a similar structural framework, although their internal architectures are different from one another. Zhu et al. (2006) studied the Cenozoic sedimentary filling pattern in the Hoh Xil, Qaidam, and Jiuquan Basins, and concluded



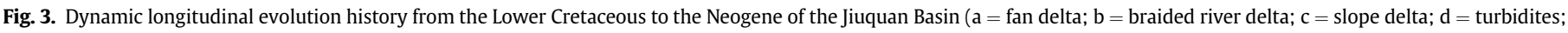
e = lacustrine) (Anderson, 1951; Jin et al., 2013; Liu, 1986; Wang et al., 2005b; Wang et al., 2008). 


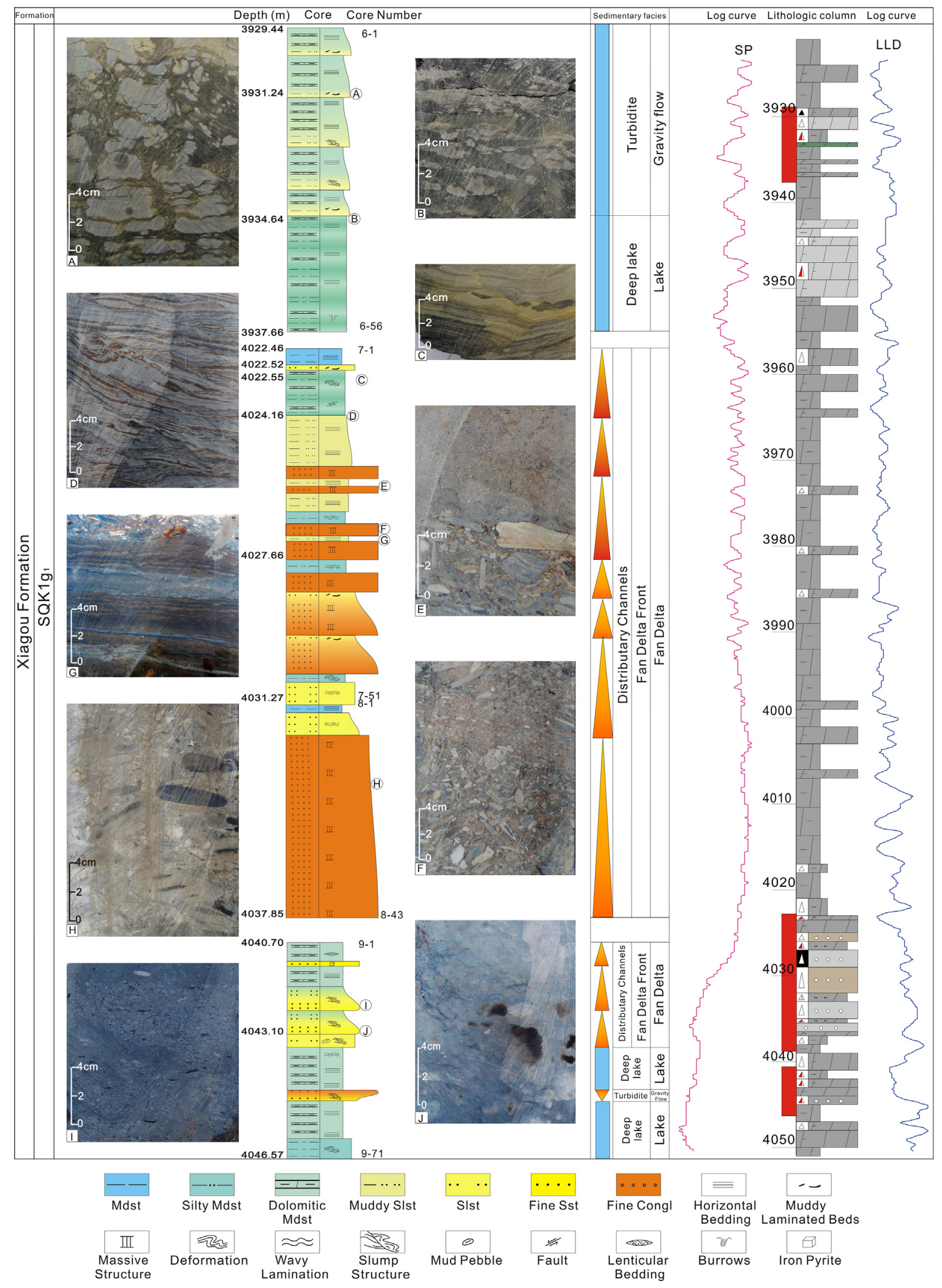

Fig. 4. Well Q8 sedimentary microfacies analysis. The $29.48 \mathrm{~m}$ cores in $\mathrm{SQK} 1 \mathrm{~g}_{1}$ occur from $4050 \mathrm{~m}$ to $3930 \mathrm{~m}$. 


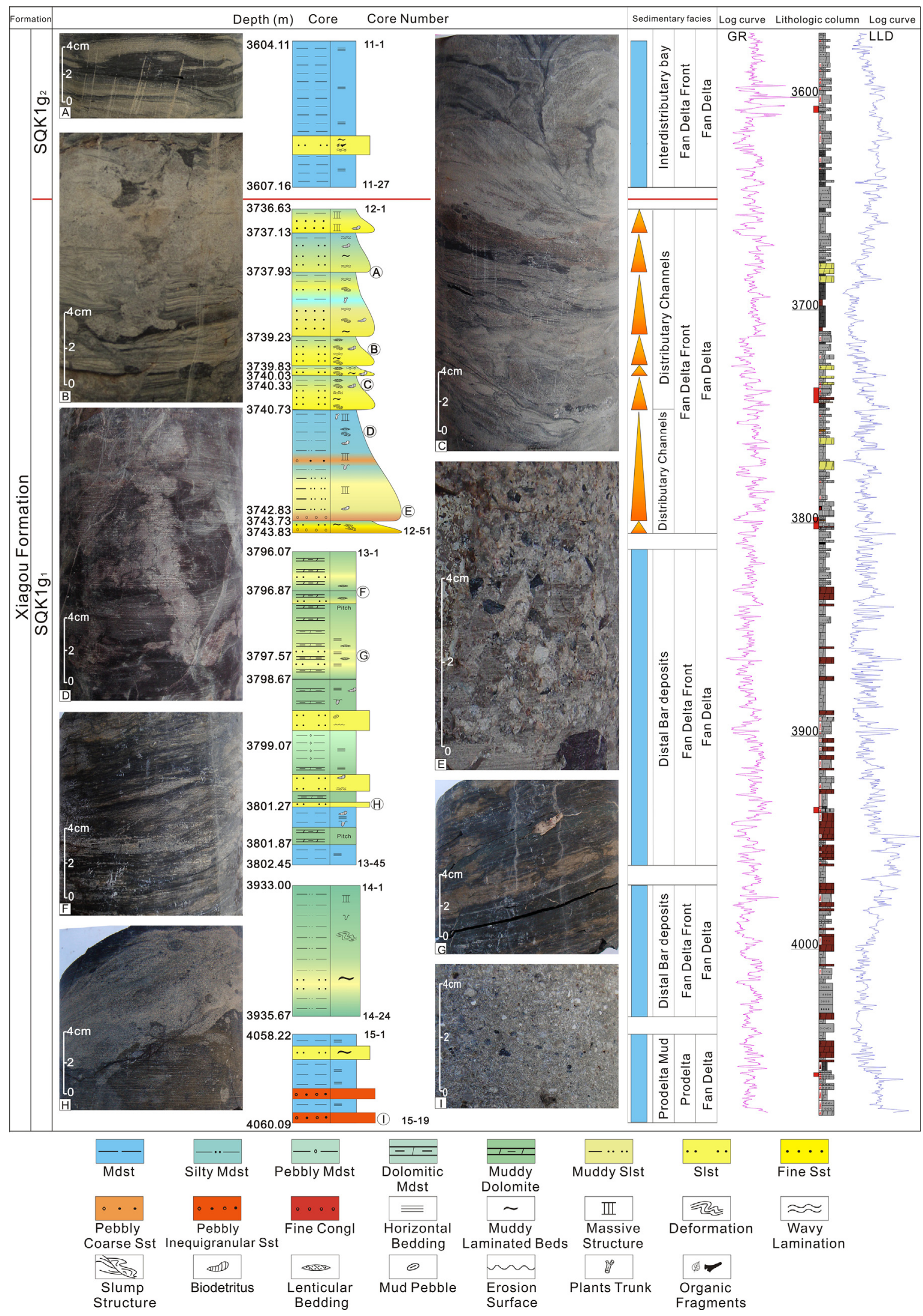

Fig. 5. Well L9 sedimentary microfacies analysis. The $21.17 \mathrm{~m}$ cores in SQK1 $\mathrm{g}_{1}$ and $\mathrm{SQK} 1 \mathrm{~g}_{2}$ occur from $4070 \mathrm{~m}$ to $3580 \mathrm{~m}$. 


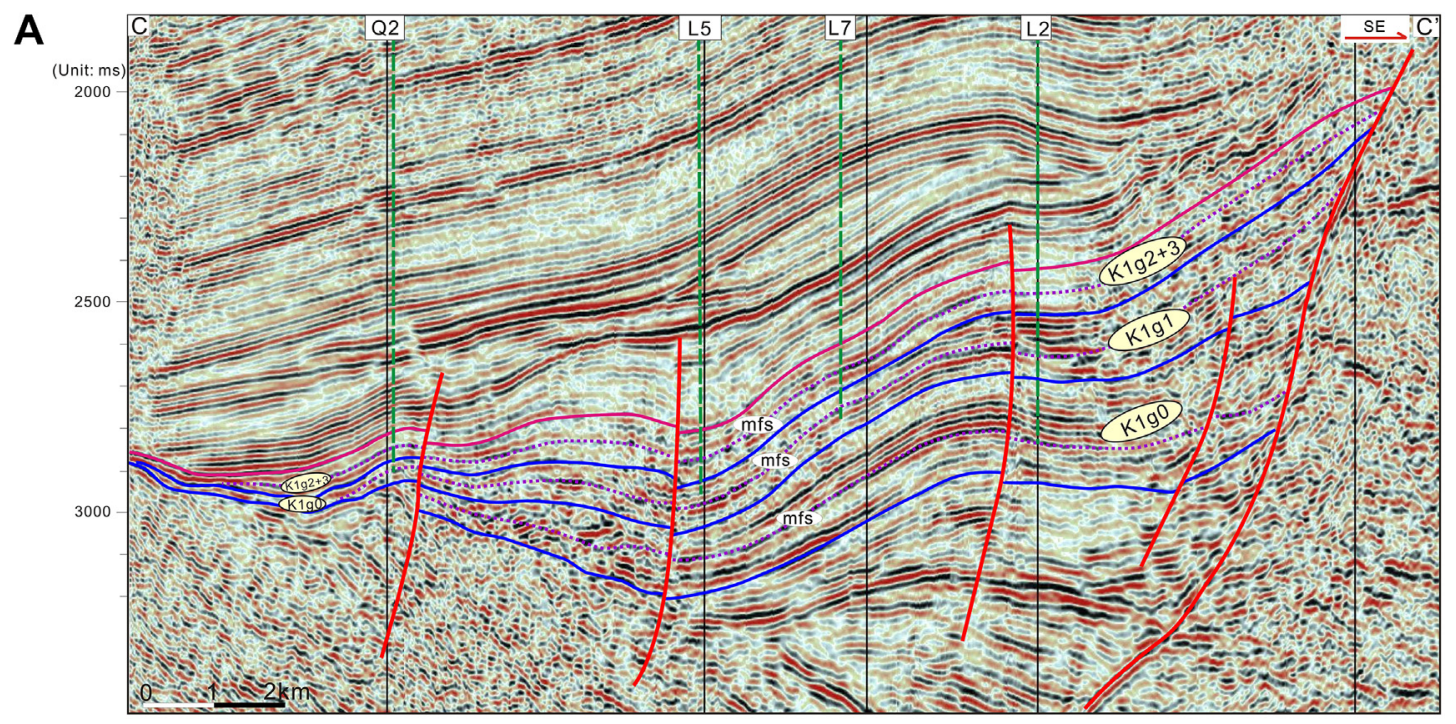

B
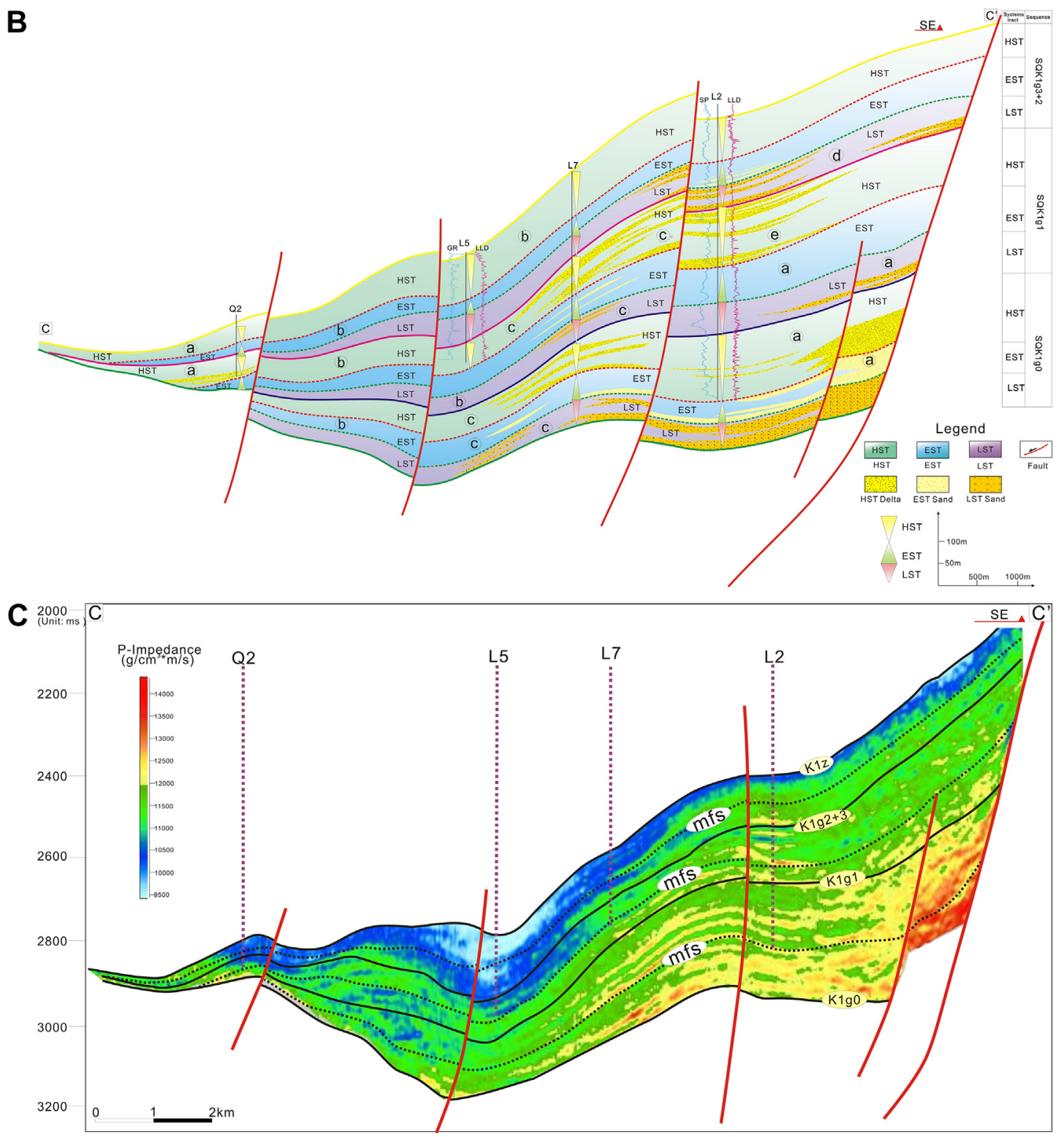
that these basins have a similar tectonic history: they began as strike-slip basins, and then evolved into foreland basins, and finally evolved into intermontane basins. The formation of foreland basins is the direct result of orogenic activity in the northeast of the Qinghai-Tibetan Plateau (Zhu et al., 2006). The northward movement of the northeast Qinghai-Tibet Plateau is one of the impact mechanisms of Cenozoic tectonic evolution, which complicates the structure of the basin. Upper Cretaceous strata are absent in the Jiuquan Basin and in many other basins in northwestern China and Central Asia, such as in the Eastern Tarim Basin, Qaidam Basin, Beishan Basin group, Ordos Basin, and Karakum Basin (Jia et al., 2003; Xiao et al., 2005). The Late Cretaceous is characterized by intensive tectonic activities in this region resulting from the collision of the Kohistan-Dras Island Arc and Lhasa Block 80-70 Ma (Graham et al., 1993; Hendrix et al., 1992). Thus, Upper Cretaceous strata was not deposited or eroded away. These tectonic activities deformed the Jurassic-Lower Cretaceous strata (Cheng et al., 2006; Jia et al., 2003).

The Jiuxi Basin in the western Hexi Corridor was influenced by the tectonic movements of the northern plateau because of its location at the junction of the two main boundary faults of the plateau: the Altyn strike-slip fault and the northern Qilian Mountains thrust (Wang et al., 2005a). The progressive northwards migration of the north Qilian Thrust in response to sinistral shearing along the $2000 \mathrm{~km}$ long Altyn Fault led to the formation of the Jiuxi Basin (Wang and Coward, 1993). The Jiuxi Basin is a foreland basin with an area of $2700 \mathrm{~km}^{2}$, which has been active since the Early Jurassic (Wang and Coward, 1993). It is bound by the Qilian Mountains marginal thrust in the south (Song et al., 2001; Vincent and Allen, 1999). It is the only basin with significant hydrocarbon accumulation in the Hexi Corridor, with proved oil and gas reserves of $1 * 10^{8}$ ton (Lei et al., 2008). The source rocks are Upper Jurassic and Lower Cretaceous lacustrine mudrocks (Vincent and Allen, 1999). The Lower Cretaceous strata in the Jiuxi Basin comprises three formations: the Chijinbao (K1c), Xiagou (K1g), and Zhonggou (K1z) Formations (Fig. 2B) (Ren et al., 2000a; Wu, 1983; Yang et al., 2002). The Qingxi Sag has an area of $540 \mathrm{~km}^{2}$ with a maximum sedimentary thickness of approximately $5000 \mathrm{~m}$, and is the most important petroliferous area in the Jiuxi Basin (Pan et al., 2006).

\subsection{Tectonic history}

The Jiuquan Basin is a Mesozoic-Cenozoic superposition basin comprising an early rifting graben phase and a later compression phase (Luo et al., 2005). Since the Early Cretaceous, the basin has undergone four major tectonic episodes: (1) extension during the Early Cretaceous, (2) tectonic inversion caused by northwestsoutheast contraction from the Late Cretaceous to the Paleocene (Pan et al., 2006), (3) weak extension from the Eocene to the Miocene, and (4) contraction from the Miocene to the present (Fig. 3) (Wang et al., 2005a; Wang et al., 2005b). Therefore, the Jiuquan Basin is the product of taphrogenic, collisional, and shearing movements.

(1) In the Early Cretaceous, the Jiuquan Basin was in the rifting stage. A lacustrine environment was the dominant depositional environment in the basin, and the Xiagou Formation was deposited then. The depositional processes were mainly controlled by the activities of a series of tensional and NE-NNE torsional growth faults (Pan et al., 2006; Sun et al., 2006; Vincent and Allen, 1999; Wang et al., 2005b). The Cretaceous grabens in the Jiuquan Basin trended nearly northeast, whereas the Neogene depression extended to the northwest. Such grabens, which trend nearly perpendicular to the strike of the entire basin or mountain chain and are characterized by extension or transtension, may be called impactogens (Burke, 1980; Li et al., 2002; Liu, 1986).

(2) During the period of the Late Cretaceous to the Paleocene, the Jiuquan Basin has experienced a strong tectonic inversion under regional compressional stress that is associated with the Late Yanshanian and Early Himalayan tectonic events. The basin was uplifted during this period, which caused widespread erosion and the absence of Shanggou Formation strata (Pan et al., 2006). No Late Cretaceous to Eocene sediments have been reported in the Jiuquan Basin (Wang and Coward, 1993). Some previous normal faults were reactivated and became reverse faults in the upper part of the basin.

(3) In the Paleogene, a thrust nappe motion caused the northern Qilian Mountains front thrust to the south (Song et al., 2001; Vincent and Allen, 1999) in the Paleogene and formed east-west trending nappe anticline structures and numerous reverse faults in the Jiuxi Depression (Fig. 1B) (Chen and Huang, 1996), which formed the structural configuration of the disrupted bruchfalten fold zone in south, the hollow zone in the central part, and the monocline zone in the north ( $\mathrm{Li}, 2003)$. This tectonic movement was caused by the collision of the Indian Plate and Eurasian plate (Zhao et al., 2004).

\subsection{Petroleum systems}

The tectonic inversion during the Late Cretaceous to the Paleocene resulted in major erosion and might have removed some potential reservoirs that were deposited before the Late Cretaceous (Wang et al., 2005a). However, many anticlines formed as a result of the structural inversion. These anticlines trapped hydrocarbons (Wang et al., 2005a). The strata subsidence after deposition of the Paleogene, thick Neogene, and Quaternary strata, caused the source rocks of the Paleozoic and Mesozoic to be deeply buried at high temperatures. Based on these conditions, the organic materials were transformed into oil and gas, which migrated along the fault fracture zones into the equal traps (Huang et al., 1993). The rifting and extensional movements promoted the mature evolution of source rocks (Pan et al., 2006). This structural modification and associated antithetic and synthetic faulting in the hanging wall largely controlled reservoir distribution, maturation, migration, and the trapping of hydrocarbons (Tankard and Welsink, 1987).

\section{Data and methodology}

The research approach is the integration of point (wells)-line (cross sections)-plane (planforms) using 3D seismic data, well logs, isopach maps, and geomorphology, which provide factual information for detecting and identifying the comprehensive and elaborate sediment infill and its evolution in longitudinal time and transverse space (Chen et al., 2011; Chen et al., 2012).

(1) Core data: two wells, Q8 and L9, with 50.65 meters of cores were described and interpreted with sedimentary microfacies analysis based on lithofacies, grain size, sedimentary structures, and trace fossils (Figs. 4 and 5).

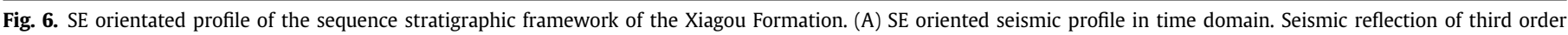

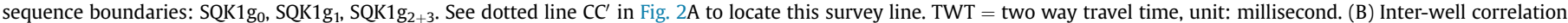

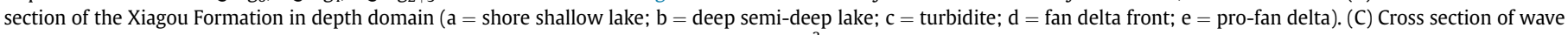
impedance inversion of the Xiagou Formation in time domain. Wave impedance unit: $\mathrm{g} / \mathrm{cm}^{3} \cdot \mathrm{m} / \mathrm{s}$. 

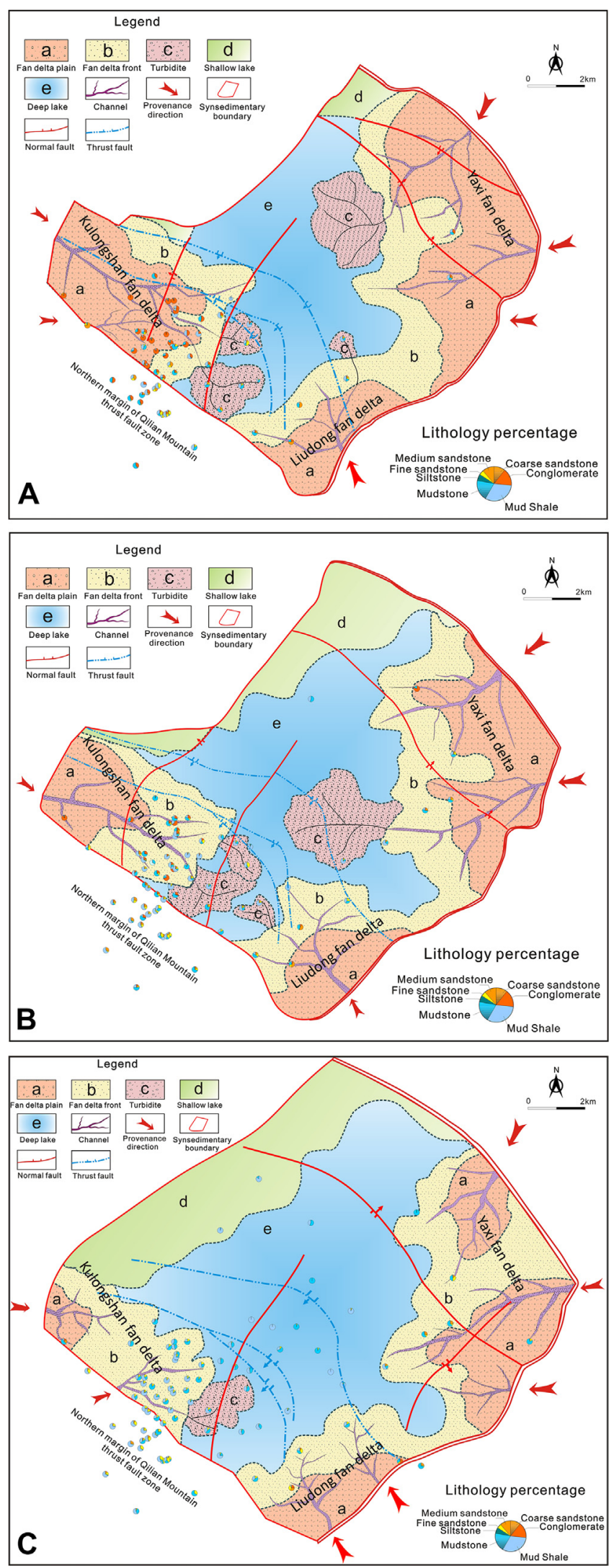

Fig. 7. Lacustrine sedimentary facies map of the Qingxi Sag ( $a=$ fan delta plain; $b=$ fan delta front; $\mathrm{c}=$ turbidite; $\mathrm{d}=$ shallow lake; $\mathrm{e}=$ deep lake). (A) SQK1 $\mathrm{g}_{0}$ sedimentary system distributions. (B) $\mathrm{SQK}_{1} \mathrm{~g}_{1}$ sedimentary system distributions. (C) SQK1 $\mathrm{g}_{2+3}$ sedimentary system distributions. The provenances came from the western Kulongshan Fan Delta, the southern Liudong Fan Delta, and the northeastern Yaxi Fan Delta.
(2) Seismic data: the 3D seismic data were acquired by PetroChina Yumen Oilfield Company. Seismic interpretations and reflection facies, such as the onlap, downlap, toplap, truncation termination reflections, and wells with synthetic seismograms, were used to infer and explain sequence boundaries, structural controls on strata morphology, fault distributions, and sedimentary structures (Catuneanu et al., 2009; Garciacaro et al., 2011). And 3 third order sequence boundaries and 3 maximum flooding surfaces were interpreted in the $284.8 \mathrm{~km}^{2}$ high resolution 3D prestack migration seismic survey of the Qingxi Sag based on horizon tracking and closing. Two seismic profiles, $\mathrm{BB}^{\prime}$ and $\mathrm{CC}^{\prime}$, were presented (Fig. $2 \mathrm{~A}, \mathrm{~B}$ and $6 \mathrm{~A}$ ) to illustrate the internal stratigraphic architecture.

(3) Inter-well correlation: four wells (Q2, L5, L7, and L2) with lithology data, SP, GR, and LLD log curves, were used in the lateral continuities and sedimentology analysis (Fig. 6B); sedimentary structure in seismic and inversion profiles were used for correlation interpretation and source analysis in inter-well or no well regions.

(4) Planar sedimentary facies: planar sedimentary facies were defined by comprehensively using the data from cores, well drillings, log curves, impedance data, and statistics (Fig. 7A,B,C). Lithological descriptions and statistics from 63 wells, which were the data sources of grain size, sandstone/mudstone ratio, and lithology percentage, were used in delimiting the types of sedimentary facies and determining sediment source entry points of the Qingxi Sag in each member; logging curve interpretations of these 63 wells were also the references for determining sedimentary facies and their lateral changes; the seismic facies, such as foreset structures, were identified as evidence for facies distributed boundaries and lobes' directions.

(5) Fault data: the fault distributions and ancient fault throw data are based on seismic interpretations and read from the 3D seismic, which were used in the fault activity rate calculation (Fig. 8A,B,C) (Lei, 2012; Li et al., 2000).

(6) Temporal evolution data: the isopach maps are from $3 \mathrm{D}$ seismic interpretation and time-depth conversion (Fig. 8A,B,C). The interpreted horizons were transformed from time domain to depth domain according to the synthetic seismogram and seismic wave velocity before being used for the thickness calculations.

(7) Subsidence history recovery: based on the stratum back stripping analysis (balance section) technique (Fig. 9) (Dahlstrom, 1969; Liu and Jiang, 1995), which recovers the older strata by stripping the overlain strata. According to the calculation of settling volume and stratal back stripping, the subsidence history of the Xiagou Formation in the Qingxi Sag has been simulated quantitatively and dynamically in both 3D volume and 2D survey lines. Thus, the various syndepositional initial landforms of the Xiagou Formation had been recovered (Li et al., 2004).

(8) Superposition of paleogeomorphology and sedimentary facies: the reconstruction and mapping of paleogeomorphology (Fig. 10) are based on the total subsidence recovery data, which provides sedimentary evolution processes and stratal geometries of each member. The stratal geometries and sedimentary facies superposition presents the coincidence between structural framework and distributions of sedimentary systems. Delineation of stratal geometries and depocenters provides evidence for interpreting depositional systems, reconstructing sediment input and dispersal patterns, and the timing and location of tectonic events (Hamlin, 2009).

The pie charts show the lithology percentages of each member with the locations of the statistic well. 


\section{Results}

\subsection{Sedimentary facies of the Xiagou Formation in the Qingxi Sag as} observed in cores

\subsubsection{Well Q8 sedimentary microfacies}

\section{Description:}

Well Q8 is at the Kulongshan nose structure in the southwest part of the Qingxi Sag (Fig. 2A). The $29.48 \mathrm{~m}$ of cores of SQK1g1 from Well Q8 are described below (Fig. 4):

- $4043.7 \mathrm{~m}$ : interbedded sandstones and dolomitic mudstones with wavy rippled laminations.

- $4043.55 \mathrm{~m}$ : gray sandstones and siltstones that contain mud pebbles up to $3 \mathrm{~cm}$ in diameter, which contain deformations and slump structures.

- $4043.2 \mathrm{~m}$ : dark gray pebbly fine sandstones that fine upward into white-gray siltstones with slump structures.

- 4041.9 m: dark gray dolomitic mudstones with horizontal beddings overlain by white-gray fine sandstones, with occasional iron pyrites, containing lenticular laminations on the top.

- 4031.27-4037.85 m: gray poorly sorted conglomerates (Fig. 4H) overlain by white-gray siltstones with ripple laminations.

- 4025.96 m: poorly sorted and moderately rounded conglomerates (Fig. 4E) with a maximum pebble diameter of $5 \mathrm{~cm}$.

- $4024.26 \mathrm{~m}$ : silty mudstones; faults with small throw $(1 \mathrm{~cm})$ and deformations are observed in this section.

- 4023.06 m: horizontally bedded dark gray dolomitic mudstones with thin, laminated silty mudstones, which contain occasional slump structures.

- 3937.66 m: grayish-green silty mudstones that are interbedded with thin laminated dark gray horizontally bedded dolomitic mudstones with burrows. The sandstone veins traverse the interbeds of the mudstones and sandstones.

- $3932.54 \mathrm{~m}$ : variegated pebbly muddy siltstones with slump structures.

- $3932.44 \mathrm{~m}$ : dark gray dolomitic mudstones with white-gray siltstones.

- $3931.64 \mathrm{~m}$ : dark gray horizontally bedded dolomitic mudstones.

- $3931.24 \mathrm{~m}$ : interbedded sandstones and dolomitic mudstones with flaser bedding and obvious loading liquefaction (Fig. 4A).

\section{Depositional environment interpretations:}

The Well Q8 cores of K1g1 show that the lithologic features are gray dolomitic mudstones with poorly sorted pebbly sandstones. The SP log curve presents the high frequency dentate characters.

The thick dolomitic mudstones indicate a relatively deep lake environment, which includes deep lake mudstone deposits and turbidites. The upward fining combination of sandstones and poorly sorted, moderately rounded conglomerates suggest distributary channels or subaqueous distributaries on the delta front of fan deltas.

\subsubsection{Well L9 sedimentary microfacies}

\section{Description:}

Well L9 is also at the Kulongshan nose structure in the southwest part of the Qingxi Sag (Fig. 2A). The $21.17 \mathrm{~m}$ of cores of SQK1g1 and SQK1g2 from Well L9 are described below (Fig. 5):

- 4058.22-4060.09 m: dark gray massive mudstones that occasionally contain 1-3 $\mathrm{mm}$ diameter white-gray lenticular siltstones. In the middle of this mudstone section, from 4059.22 to $4059.42 \mathrm{~m}$, is a $20 \mathrm{~cm}$ thick bed of poorly sorted pebbly sandstone with grain diameters of $1-2 \mathrm{~mm}$.

- 3933.00-3935.67 m: dark gray silty mudstones of massive structure with burrows and abundant deformations, and occasionally slickolites and calcium fillings. The mudstone section contains a $5 \mathrm{~cm}$ thick white-gray siltstone bed with dark gray argillaceous laminations at 3934.9-3935.4 m.

- 3801.27-3802.45 m: dark gray dolomitic mudstones of massive structure with abundant borrows and rare biodetritus. It contains a $40 \mathrm{~cm}$ thick brown muddy dolomite bed with muddy bitumen fissure fillings at 4058.62-4059.02 m.

- 3798.67-3801.27 m: dark gray horizontally bedded dolomitic mudstones with intensive bioturbations, and rare slickolites. 3799.27-3799.37 m: white-gray siltstones with mud pebbles and erosion surface.

3799.67-3799.87 m: dark gray pebbly dolomitic mudstones. 3800.67-3800.72 m: white-gray fine sandstones with minor bioturbations and wavy laminations.

- 3796.87-3798.67 m: the lower part is characterized by maroon dolomitic mudstones overlain by gray horizontally bedded dolomitic mudstones, and then changes into taupe muddy dolomites with bitumen at the top.

- 3743.73-3743.83 m: poorly sorted and rounded $1 \mathrm{~mm}-1 \mathrm{~cm}$ diameter conglomerates with slump structures and deformations. The conglomerates gradually change upwards into white-gray massive siltstones with muddy laminae and deformations.

- 3740.73-3743.73 m: this section starts with poorly sorted and rounded $3 \mathrm{~mm}-1 \mathrm{~cm}$ diameter conglomerates (Fig. 5E), and fines upward into gray muddy massive siltstones that contain abundant bioturbations, and then is overlain by maroon silty mudstones of massive structure with thin laminated pebbly coarse sandstones, which contain bioturbations and burrows. The uppermost part of the section consists of dark gray massive mudstones with thin lenticular sandstones and plant stem fossils within paleosol.

- 3739.23-3740.73 m: three groups of white-gray siltstones with wavy rippled muddy laminae and deformations that fine upward into dark gray mudstones with white lenticular siltstones, deformations, and rare bioturbation (Fig. 5B,C).

- 3737.93-3739.23 m: white-gray fine-grained sandstones with wavy muddy laminae and deformations, as well as biodetritus, that fine upward into dark gray mudstones with white-gray wavy siltstones, containing plant stems, slickolites, and deformations.

- 3737.13-3737.93 m: interbedded wavy white-gray siltstones and dark gray mudstones with biodetritus (Fig. 5A).

- 3736.63-3737.13 m: white-gray pure fine sandstones of massive structure with biodetritus change upward into white-gray pure siltstones of massive structure.

- 3604.11-3607.16 m: dark gray horizontally bedded mudstones contain a bed of white-gray wavy siltstones with occasional plant fragments and dark gray muddy laminae at 3606.11$3606.41 \mathrm{~m}$.

\section{Depositional environment interpretations:}

The Well L9 core shows the SQK1g1 and SQK1g2 sequence. The core section consists of brown and taupe muddy or calcite dolomite, gray dolomitic fine sandstones, and pebbly sandstones, as well as dark gray dolomitic mudstones. The SP log curve has a low frequency dentate shape.

The dolomitic mudstones and mudstones of this section are interpreted to be deposited in a prodelta environment. The upward fining sequences of interbedded siltstones and mudstones are 

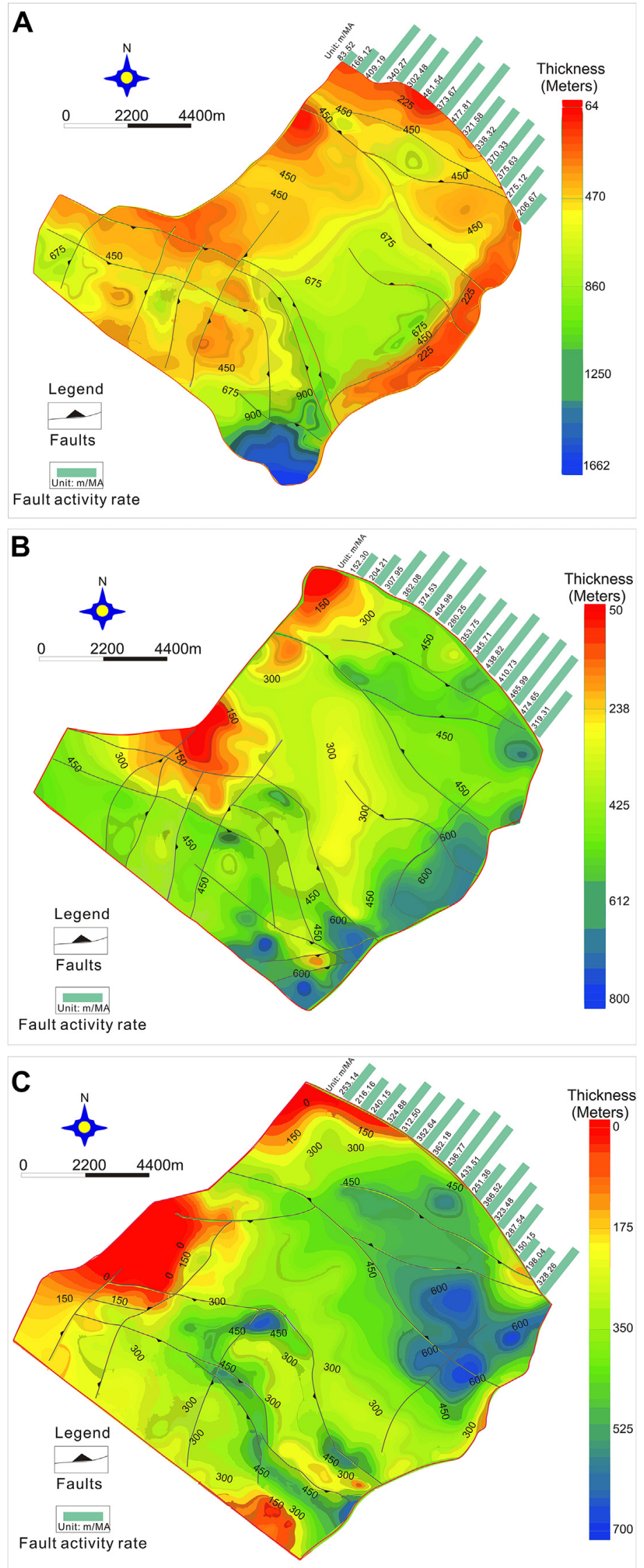

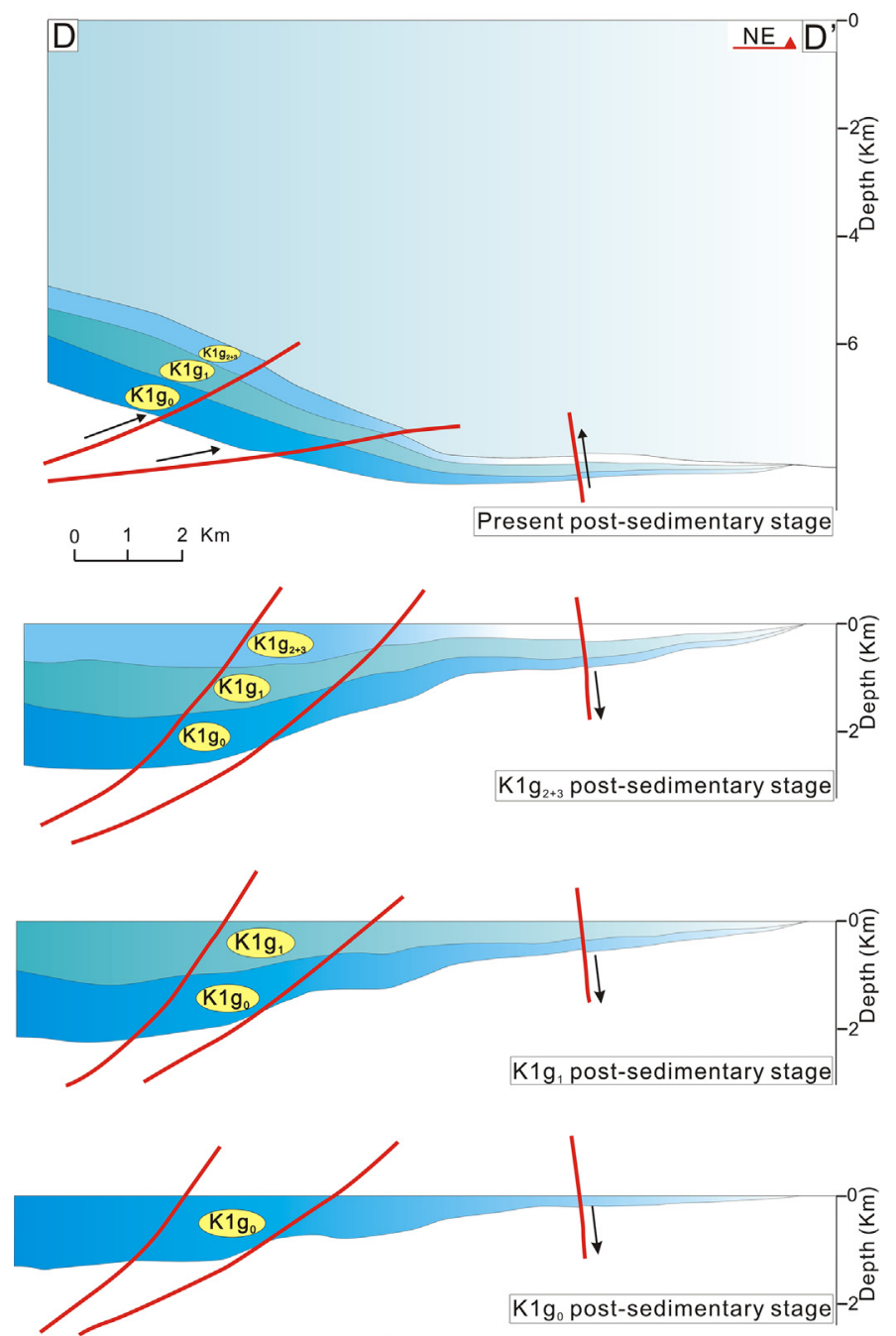

A

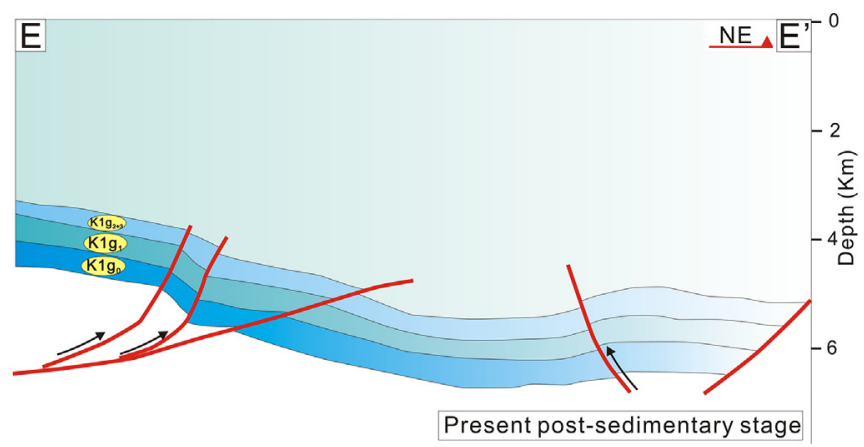

$0 \quad 1 \quad 2 \mathrm{Km}$
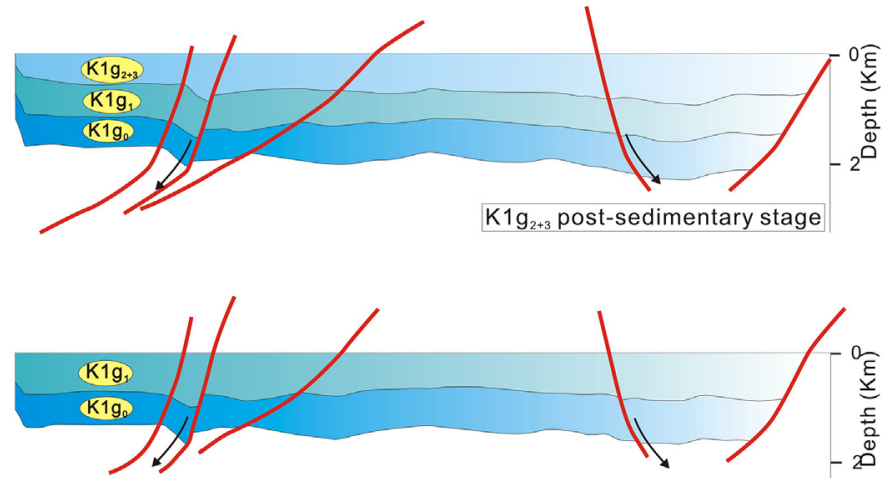

$\mathrm{K} 1 \mathrm{~g}$, post-sedimentary stage

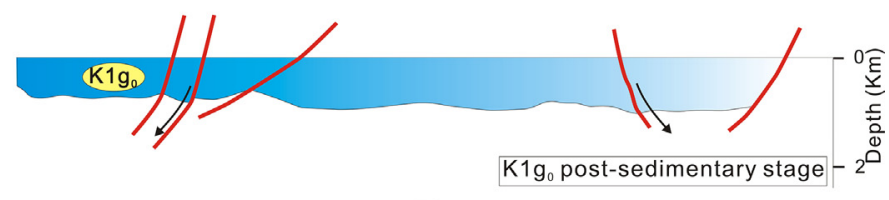

B

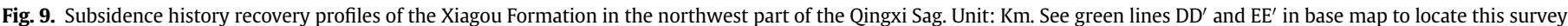
line. (For interpretation of the references to colour in this figure legend, the reader is referred to the web version of this article.)

interpreted as subaqueous distributaries on the distal end of a fan delta front or prodelta.

It is therefore interpreted that the area of the L9 well was at a more distal position compared to the Q8 well. In the L9 well, prodelta facies overlie the deep lake mudstones. Additionally, the L9 well has a lower conglomerate content, which is consistent with the interpretation of deposition at a more distal location.

\subsection{Inter-well correlation sequence stratigraphy framework and sediment infill features}

The NW-SE seismic profile (Fig. 6A), which crosses wells Q2, L5, L7, and L2, shows the inner structures and strata architectures of the Xiagou Formation in the Qingxi Sag (See Fig. 2A for the plan location of this profile). Three third order sequence boundaries and their corresponding maximum flooding surfaces were interpreted with 3D seismic data, which are: SQK1 $g_{0}, \mathrm{SQK}_{1} \mathrm{~g}_{1}$, and $\mathrm{SQK} 1 \mathrm{~g}_{2+3}$. Controlled by five northeast trend reverse faults, the sag represents a half-graben shape, which presents the boundary fault and greater strata thickness in the east and gradually thinning strata and onlap to the west. The internal structure of strata and the presence of reverse faults indicate a tilting trend that formed after deposition as a result of foreland loading and over thrusting during the Pliocene (Chen et al., 2006; Li et al., 2002). Equal strata thickness near the hanging wall and the footwall of the faults also suggests that the reverse faults formed during a post sedimentary period of the Xiagou Formation.

Inter-well correlation section $\mathrm{CC}^{\prime}$ (Fig. 6B), which intersects Wells Q2, L5, L7, and L2, was interpreted based on the seismic profile CC' (Fig. 6A). Wells Q2, L5, and L7 penetrated SQK1 $\mathrm{g}_{1}$, and L2 drilled through $\mathrm{K}_{1} \mathrm{~g}_{0}$. Additionally only $\mathrm{SQK}_{1} \mathrm{~g}_{1}$ and $\mathrm{SQK} 1 \mathrm{~g}_{2+3}$ developed near Well Q2. The maximum deposit thickness of drilling wells is approximately $5000 \mathrm{~m}$. The inter-well correlation section shows a half-graben with onlap in the west and a boundary fault in east (Pan et al., 2006; Sun et al., 2006).

The well logging-constrained seismic inversion section of $\mathrm{CC}^{\prime}$ shows both the seismic wave impedance features and the well logging-constrained factor (Fig. 6C). The red and yellow (in the web

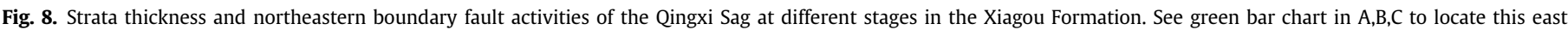

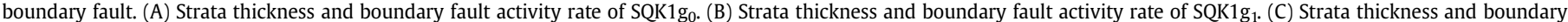

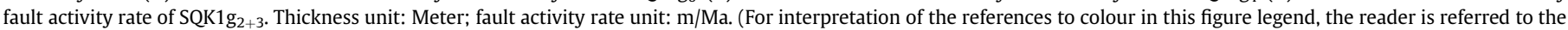
web version of this article.) 

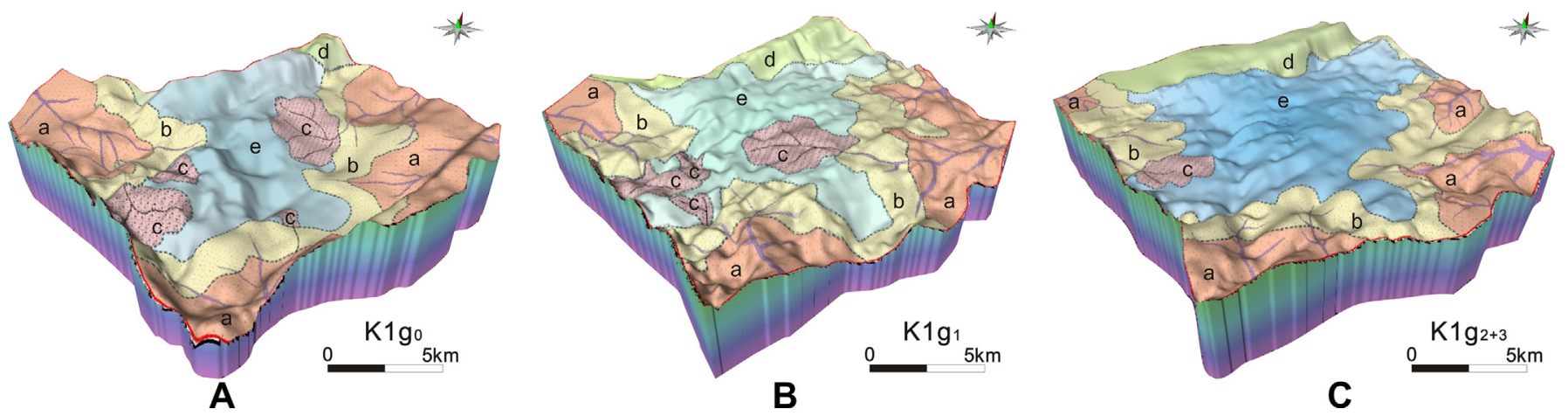

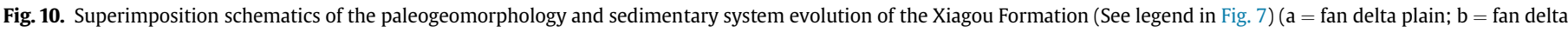

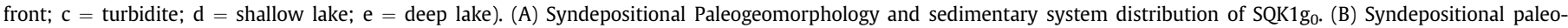
geomorphology and sedimentary system distribution of SQK1 $\mathrm{g}_{1}$. (C) Syndepositional Paleogeomorphology and sedimentary system distribution of SQK1g $\mathrm{g}_{2+3}$.

version) in the wave impedance section indicate a relatively higher value of impedance between 12,000 and $14,300 \mathrm{~g} / \mathrm{cm}^{3} \cdot \mathrm{m} / \mathrm{s}$, and the green and blue represent lower values ranging from 9,500 to $12,000 \mathrm{~g} / \mathrm{cm}^{3} \cdot \mathrm{m} / \mathrm{s}$. The inversion profile presents prograding clinoforms from east or northeast sources during $\mathrm{K}_{1} \mathrm{~g}_{0}$ and $\mathrm{K} 1 \mathrm{~g}_{1}$, and northeast sources near well L2 during $\mathrm{K} \mathrm{g}_{2+3}$.

According to comprehensive analyses of the lithology in the wells, seismic sedimentary facies, and wave impedance inversion, section $\mathrm{CC}^{\prime}$ indicates that sediment sources came from the east and northeast, which were commonly developed in the Xiagou Formation. During $\mathrm{K}_{1} \mathrm{~g}_{0}$, the deposit sources of the lowstand system tract (LST) came from the eastern and northeastern Yaxi Fan Delta, which passed the location of well L2 and extended to well L7. Additionally the lacustrine extended system tract (EST) and highstand system tract (HST) represent deep lake or fairly deep lake environments. During $\mathrm{SQK}_{1} \mathrm{~g}_{1}$, the deposits came from the northeast, which shows an oblique direction from the section. It developed a fan delta front at well L2 and turbidites at well L7 and L5. During the K1 $\mathrm{g}_{2+3}$ periods, fan delta front deposits developed near well L2 in the LST.

\subsection{Temporal and spatial evolution of plane sedimentary facies distributions of the Xiagou Formation}

Based on the core analysis, well drilling, log curves, wave impedance data, and lithology percentage statistics (as shown in Fig. 7), the plane sedimentary facies of Qingxi Sag were defined. Controlled by boundary faults, the Qingxi Sag received contributions from three sediment sources located to the west, south, and northeast during deposition of the Xiagou Formation (See the red arrow (in the web version) in Fig. 7 as the source direction in the Qingxi Sag), which comprised three main fan delta systems called the Kulongshan, Liudong, and Yaxi (Fig. 7). There are two sets of secondary faults in the sag that controlled the distribution of the subfacies. The normal faults, which are shown in red in Fig. 7 in the southwest part of basin, control the facies distribution of the Kulongshan Fan Delta. The normal faults in the northeast part, to some extent, determined the development of the Yaxi Fan Delta. The thrust faults (shown in blue dotted line in Fig. 7), which were normal faults during the depositional stage, were formed by a thrust nappe motion and reformed the sediment infill.

Five sedimentary facies associations were identified in the Qingxi Sag: the shoreland plain, the fan delta dominated sedimentary system (including fan delta plains, delta fronts, and prodelta), turbidite deposits, shallow lakes, and half-deep lake systems. Sediments shed from the Qilian Mountains at the northern margin of the Tibetan Plateau, are widely deposited in the Jiuxi Basin (Song et al., 2001). The characteristics of these depositional systems and their spatial movements of facies and facies associations through time reflect pervasive structural control affecting the distribution of facies tracts (Tankard and Welsink, 1987). From K1 $\mathrm{g}_{0}$ to $\mathrm{K} \mathrm{g}_{2+3}$, decreased sandstone percentage in the Kulongshan Fan Delta area indicates a transgressive process, which shows the transition from a proximal to a distal site in most statistic wells. The Kulongshan Fan Delta developed continuously, the northeastsouthwest faults control the distributions of sedimentary subfacies, which develop delta fronts and turbidite fans lakeward. Because of the transgressive process during the $\mathrm{K} \mathrm{g}_{2+3}$ periods, the scale of the fan delta obviously decreased. Similar to the Kulongshan Fan Delta, the Liudong and Yaxi Fan Deltas developed continuously with turbidite fans in the front of the delta fronts from $\mathrm{K} 1 \mathrm{~g}_{0}$ to $\mathrm{K} 1 \mathrm{~g}_{1}$ and at a reduced scale during $\mathrm{K} 1 \mathrm{~g}_{2+3}$.

\section{Discussions}

Sediment fill in a basin is inseparable from multiple interdependent factors, such as tectonic activity, basin subsidence, paleogeomorphology, sediment supply, and depositional systems. On one hand, the tectonic temporal evolution during the Early Cretaceous control the sediment infill in the Qingxi Sag, but on the other hand, the sedimentation responds to the tectonic activities.

\subsection{Northeastern boundary fault activity}

The activity of growth faults was calculated based on the fault fall analysis (Zhao and Dai, 2003), which proclaims the control of the boundary fault on the sedimentary distributions of the Yaxi Fan Delta. The middle part of the northeastern boundary fault was very active during $\mathrm{K} \mathrm{g}_{0}$ to $\mathrm{K}_{1} \mathrm{~g}_{2+3}$, whereas the eastern part was more active than the western part during $\mathrm{K}^{1} \mathrm{~g}_{1}$ (Fig. 8B). Fault activity of the western part decreased gradually through time. Along the eastern part of the northern boundary, fault activity initially increased from $\mathrm{K}_{1} \mathrm{~g}_{0}$ to $\mathrm{K}_{1} \mathrm{~g}_{1}$ and then decreased during $\mathrm{K} 1 \mathrm{~g}_{2+3}$ (Fig. 8). In general, the eastern part of the northern boundary fault is more active than the western part, which has an important influence on the northeastward migration of depocenters and the development of the Yaxi Delta in the Xiagou Formation (Fig. 8). The average fault activities of each period are $323.02 \mathrm{~m} / \mathrm{Ma}$ during $\mathrm{K} 1 \mathrm{~g}_{0}$, $350.90 \mathrm{~m} / \mathrm{Ma}$ during $\mathrm{K}_{1} \mathrm{~g}_{1}$, and $302.33 \mathrm{~m} / \mathrm{Ma}$ during $\mathrm{K} \mathrm{g}_{2+3}$, which indicates an increased and then decreased trend of fault activities.

\subsection{Strata thickness responses to the tectonic activities}

The general strata thickness distribution trend of the north and northwest part of the Qingxi Sag are persistent during three stages, 
which are shown by the relative thin thickness area of the sag (Fig. 8). The thickest depocenter was at the southernmost part of the Qingxi Sag during K1 $\mathrm{g}_{0}$, which had dispersed and migrated gradually to the peripheral area near the NW-SE trending faults (Fig. 8ABC). Additionally, the orientation of the depocenter was parallel with the strike of the faults (Fig. 8C) (Zhu et al., 2006). The main depocenter of the Qingxi Sag had migrated northeastwards from $\mathrm{K}_{1} \mathrm{~g}_{0}$ to $\mathrm{K} \mathrm{g}_{2+3}$, with the maximum thickness decreased from $1662 \mathrm{~m}$ to $700 \mathrm{~m}$. The entire structural framework has changed from deep in the south and shallow in the north during $\mathrm{K} \mathrm{g}_{0}$ and $\mathrm{K} \mathrm{g}_{1}$ to the trending of deep in the east and shallow in the west in $\mathrm{K} \mathrm{g}_{2+3}$, indicating an anticlockwise rotation and migration.

\subsection{Subsidence history of the Xiagou Formation}

The subsidence history recovery of the Qingxi Sag was quantitatively studied using the back stripping analysis (balance section) technique, which calculates both the total subsidence and tectonic subsidence and reproduces the sedimentary evolution process. During the Early Cretaceous, the basin subsided continuously at an average rate of $6.2 \mathrm{~cm} / 1000 \mathrm{yr}$ (Wang and Coward, 1993). The sedimentary evolution survey line $\mathrm{DD}^{\prime}$ is along the northwestern margin of the Qingxi Sag (Fig. 9A). The depocenters of survey line $\mathrm{DD}^{\prime}$ were located near the southwestern Kulongshan thrust belt and pinched out gradually to the northeast. The thicker southern strata and relatively thinner strata in the north developed continuously from $\mathrm{K} 1 \mathrm{~g}_{0}$ to $\mathrm{K}_{1} \mathrm{~g}_{2+3}$. The strata thickness of survey line $\mathrm{EE}^{\prime}$ (Fig. 9B), which is more to the east and parallel to $\mathrm{DD}^{\prime}$, was relatively homogeneous during $\mathrm{K} \mathrm{g}_{0}$ to $\mathrm{K}_{1} \mathrm{~g}_{2+3}$, with a slightly increased thickness in the northeast. Subsequent structural inversion during the Late Cretaceous to the Paleocene made the fault throw of the synsedimentary faults decline or vanish in the strata of the Xiagou Formation. As the Qilian Mountain Uplift intensified, the southern piedmont strata were tilted in both $\mathrm{DD}^{\prime}$ and $\mathrm{EE}^{\prime}$ profiles; this appears as a north dipping monocline in the Qingxi Sag. The compression of southwest to northeast tectonic stress formed thrust faults and anticlines, which provided migration pathways for hydrocarbon reservoirs.

\subsection{Geomorphology and sedimentary evolution of the Xiagou Formation}

The geomorphology of the depositional stage influences the development and distribution of sedimentary systems. The Paleogeomorphology of the Qingxi Sag can be reconstructed by back stripping using 3D seismic interpretation and time-depth conversion. From SQK1g $g_{0}$ to SQK1 S2+3 $_{2}$ (Fig. 10), the topography developed continuously, but the subsidence diminished from intensive in the early period to relatively gentle in the later period, which indicates a geological process that shifts from intense fault rifting to overall subsidence in the Lower Cretaceous from the Xiagou to the Zhonggou Formation. In the early stage, fault control is the highimpact factor; by contrast, depression dominates sag filling later (Chen et al., 2012). Based on this tectonic background, the sediment system developed continuously throughout the depositional stage of the Xiagou Formation, but the scale and progradation of fan deltas declined from SQK1g $\mathrm{g}_{0}$ to $\mathrm{SQK}_{1} \mathrm{~g}_{1}$ (Fig. 10A,B). This period was followed by a transgression with increased water depth. Lake areas enlarged during the SQK $1 \mathrm{~g}_{2+3}$ stage with the development of a delta plain in the northwestern part of the Qingxi Sag (Fig. 10C).

\section{Conclusions}

(1) Five sedimentary facies associations were identified in the Qingxi Sag: the shoreland plain, the fan delta dominated sedimentary system (including fan delta plains, delta fronts and prodelta), turbidite deposits, shallow lakes and halfdeep lake systems.

(2) From $\mathrm{K} 1 \mathrm{~g}_{0}$ to $\mathrm{K} 1 \mathrm{~g}_{2+3}$, the decreased sandstone percentage in three fan delta areas indicates a continuously transgressive process overall during the Xiagou Formation period, which exhibits a transition from a proximal to a distal site from the lake in most statistic wells.

(3) The three fan deltas that were inherited developed from $\mathrm{K} \mathrm{g}_{0}$ to $\mathrm{K} \mathrm{g}_{2+3}$ with an obviously decreasing delta scale as the area of the lake basin increased.

(4) The sediment fill was controlled by syndepositional tectonics. The more active eastern part of the northern boundary fault, where fault activities increased first and then decreased, has an important influence on the northeastward migration of depocenters in the Xiagou Formation.

(5) The topography developed continuously from $\mathrm{K} \mathrm{g}_{0}$ to $\mathrm{K} \mathrm{g}_{2+3}$, but the diminished subsidence indicates the dominant geological process varying from intense fault rifting in an early period to relatively gentle and overall subsidence in a later period during the Early Cretaceous.

\section{Acknowledgments}

This paper benefited from the abundant valuable data provided by the PetroChina Yumen Oilfield Company. We thank the Key Laboratory of Tectonics and Petroleum Resources, Ministry of Education (Grant No. TPR-2011-09) and project of "Double strong effect, driving mechanism and hydrocarbon significance of tectonic activity during depositional period of Dongying Formation in Qikou and Nanpu Sag, Eastern China" (Grant No. 41272122) for their financial supports. Thanks to the China University of Geosciences for their administrative support. We thank editor Dr. Eduardo Koutsoukos and anonymous reviewers, whose comments and suggestions have helped improving the original manuscript. Also, the authors would like to extend their sincere gratitude to the considerable help given by colleagues of PetroChina Yumen Oilfield Company. Dr. Detian Yan is thanked for a constructive review of an early draft of this paper. Thanks also to Doctoral student Patricia Bobeck for her help in correcting the English.

\section{References}

Anderson, E.M., 1951. The dynamics of faulting, Etc (Revised). Edinburgh, London. Burke, K., 1980. Intracontinental rifts and aulacogens. In: National Research Council (Ed.), Continental Tectonics. National Academy of Science, Washington, pp. 42-49. Catuneanu, O., Abreub, V., Bhattacharya, J.P., Blum, M.D., Dalrymple, R.W., Eriksson, P.G., Fielding, C.R., Fisher, W.L., Galloway, W.E., Gibling, M.R., Giles, K.A., Holbrook, J.M., Jordan, R., Kendall, C.G.S.C., Macurda, B., Martinsen, O.J., Miall, A.D., Neal, J.E., Nummedal, D., Pomar, L., Posamentier, H.W., Pratt, B.R., Sarg, J.F., Shanley, K.W., Steel, R.J., Strasser, A., Tucker, M.E., Winker, C., 2009. Towards the standardization of sequence stratigraphy. Earth-Science Reviews 92, 1-33.

Chen, H., Yang, S., Xiao, A., Pan, Z., Cheng, X., Chen, J., Fan, M., Tian, D., 2006 Deformation characteristics and time of Cenozoic thrust belt in southern margin of Jiuquan Basin. Oil \& Gas Geology 27, 488-494 (in Chinese, English abstract).

Chen, J.P., Huang, D.F., 1996. Formation and mechanism of the abnormal pressure zone and its relation to oil and gas accumulations in the Eastern Jiuquan Basin, northwest China. Science in China Series D 39, 194-204 (in Chinese, English abstract).

Chen, S., Wang, H., Zhou, L.H., Huang, C.Y., Ren, P.G., Wang, J.H., Liao, Y.T., Xiang, X.M., Xia, C.Y., 2011. Recognition and depiction of special geologic bodies of Member 3 of Dongying Formation in Littoral Slope Zone, Qikou Sag. Journal of Central South University of Technology 18, 898-908.

Chen, S., Wang, H., Zhou, L.H., Huang, C.Y., Wang, J.H., Ren, P.G., Xiang, X.M., 2012 Sequence thickness and its response to episodic tectonic evolution in Paleogene Qikou Sag, Bohaiwan Basin. Acta Geologica Sinica-English Edition 86, 10771092.

Cheng, X., Zheng, D., Yang, S., Chen, H., 2006. A study on characteristics of the Late Cretaceous-Paleocene structures in Jiuquan Basin. Oil \& Gas Geology 27, 522527 (in Chinese, English abstract). 
Dahlstrom, C., 1969. Balanced cross sections. Canadian Journal of Earth Sciences 6, $743-757$.

Garciacaro, E., Escalona, A., Mann, P., Wood, L., Moscardelli, L., Sullivan, S., 2011 Structural controls on Quaternary deepwater sedimentation, mud diapirism, and hydrocarbon distribution within the actively evolving Columbus foreland basin, eastern offshore Trinidad. Marine and Petroleum Geology 28, 149-176.

Graham, S., Hendrix, M., Wang, L., Carroll, A., 1993. Collisional successor basins of western China: Impact of tectonic inheritance on sand composition. Geological Society of America Bulletin 105, 323-344.

Hamlin, H.S., 2009. Ozona sandstone, Val Verde Basin, Texas: Synorogenic stratigraphy and depositional history in a Permian foredeep basin. AAPG Bulletin 93, $573-594$.

Han, Y., Hu, Y., Wang, C., Yang, Z., 2007. The differences between two oil-enriched sags and their exploration prospects in Jiuquan Basin. Xinjiang Petroleum Geology 28, 691-693 (in Chinese, English abstract).

Hendrix, M.S., Graham, S.A., Carroll, A.R., Sobel, E.R., McKnight, C.L., Schulein, B.J., Wang, Z., 1992. Sedimentary record and climatic implications of recurrent deformation in the Tian Shan: Evidence from Mesozoic strata of the north Tarim, south Junggar, and Turpan basins, northwest China. Geological Society of America Bulletin 104, 53-79.

Huang, H., Zheng, G., Fang, G., Xia, Y., 1993. Nappe structures in south margin of Jiuxi Basin and its oil-bearing area. Oil \& Gas Geology 14, 181-190 (in Chinese, English abstract).

Jia, C., Chen, H., Yang, S., Lu, H., Zhou, Y., 2003. Late Cretaceous uplifting process and its geological response in Kuqa depression. Acta Petrolei Sinica 24, 2-6 (in Chinese, English abstract).

Jin, S.D., Wang, H., Chen, S., Gan, H.J., Lv, Z.Y., 2013. The control of nose structure on depositional system and its geological significance for petroleum in Changshaling, Yinger Sag, eastern Jiuquan Basin. Journal of Earth Science 24, (in press).

Lei, B., 2012. Review of methods with quantitative studies of activity intensity of the growth fault. Advances in Earth Science 27, 947-956 (in Chinese, English abstract).

Lei, M., Wei, W., Shu, Z., He, X., 2008. Rethinking the practice of petroleum exploration in the Hexi Corridor area. Petroleum Geology and Experiment 30, 542546 (in Chinese, English abstract).

Li, F., 2003. New evidence for the presence of the NS-trending extensional structures in northwestern China: An example from the Early Cretaceous halfgraben fault depressions in Jiuquan, Gansu. Sedimentary Geology and Tethyan Geology 23, 35-42 (in Chinese, English abstract).

Li, F., Wang, C., Wang, C., 2006. Tectonic characteristics and origin of Jiuquan Basin group. Acta Geologica Sinica 80, 181-191 (in Chinese, English abstract).

Li, Q., Luo, F., Miao, C., 2000. Research on fault activity ratio and its application. Fault-block Oil and Gas Field 7, 15-17 (in Chinese, English abstract).

Li, S., Xie, X., Wang, H., Jiao, Y., Ren, J., Zhuang, X., Lu, Y., 2004. Sedimentary Basin Analysis Principle and Application. Higher Education Press, Beijing (in Chinese).

Li, X., Guo, Y., Wang, X., Ding, Z., Wan, Y., 2002. Nappe structural characteristics in southern margin of Jiuquan Basin and its orientation for hydrocarbon prospecting. Xinjiang Petroleum Geology 23, 299-301 (in Chinese, English abstract).

Lin, C., 2009. Sequence and depositional architecture of sedimentary basin and process responses. Acta Sedimentologica Sinica 27, 849-862 (in Chinese, English abstract).

Liu, G., Jiang, L., 1995. Balanced section technique and seismic data interpretation. Oil Geophysical Prospecting 30, 833-844 (in Chinese, English abstract).

Liu, H.F., 1986. Geodynamic scenario and structural styles of Mesozoic and Cenozoic basins in China. AAPG Bulletin 70, 377-395.

Luo, Z., Pan, L., Zhang, H., Zhang, J., Li, M., 2005. The characteristics of sequence stratigraphy and lithological exploration target in Ying'er Depression of Jiuquan Basin, Gansu Province. Geo Science 19, 563-569 (in Chinese, English abstract).
Pan, L., Xie, J., Li, M., Zheng, M., 2006. Cretaceous - Cenozoic regional tectonic evolution in Jiuquan Basin and petroleum exploration. Oil \& Gas Geology 27, 62-69 (in Chinese, English abstract).

Ren, J., Lin, C., Li, S., Jiao, G., 1999. Sequences stratigraphic framework of Wuliyasitai faulted basin in Erlian Basin group and its episodic filling evolution. Acta Sedimentologica Sinica 17, 553-559 (in Chinese, English abstract).

Ren, Z., Liu, C., Zhang, X., Wu, H., 2000a. Research on the Relation between Geothermal History and Oil-Gas Generation on Jiudong Basin. Acta Sedimentologica Sinica 18, 619-623 (in Chinese, English abstract).

Ren, Z.L., Liu, C.Y., Zhang, X.H., Wu, H.N., Chen, G., Li, J.B., Ma, T.X., 2000b. Recovery and comparative research of thermal history on Jiuquan Basin group. Chinese Journal of Geophysics-Chinese Edition 43, 635-645 (in Chinese, English abstract).

Shi, Z.T., Ye, Y.G., Zhao, Z.J., Fang, X.M., Li, J.J., 2001. ESR dating of late Cenozoic molassic deposits in the Jiuxi Basin. Science in China Series D 44, 203-209.

Song, C.H., Fang, X.M., Li, J.J., Gao, J.P., Zhao, Z.J., Fan, M.J., 2001. Tectonic uplift and sedimentary evolution of the Jiuxi Basin in the northern margin of the Tibetan Plateau since 13 Ma BP. Science in China Series D 44, 192-202.

Sun, T., Pan, L., Zhang, H., Zhao, J., Ma, G., Liu, Y., 2006. Study of tectono-stratigraphic reservoir prospecting in Jiuquan Basin. Oil Geophysical Prospecting 41, $37-41$ (in Chinese, English abstract).

Tankard, A.J., Welsink, H.J., 1987. Extensional tectonics and stratigraphy of Hibernia Oil-Field, Grand-Banks, Newfoundland. AAPG Bulletin 71, 1210-1232.

Vincent, S.J., Allen, M.B., 1999. Evolution of the Minle and Chaoshui Basins, China: Implications for Mesozoic strike-slip basin formation in Central Asia. Geological Society of America Bulletin 111, 725-742.

Wang, B.Q., Chen, H.L., Yang, S.F., Xiao, A.C., Cheng, X.G., Rupp, J.A., 2005a. Geometry and kinematics of Late Cretaceous inversion structures in the Jiuquan Basin, western China. Cretaceous Research 26, 319-327.

Wang, C., Ma, G., Zhou, Z., 2005b. Structure evolution and sedimentary filling of Jiuquan Basin in Mesozoic-Cenozoic Period, NW China. Petroleum Exploration and Development 32, 33-36 (in Chinese, English abstract).

Wang, M., Wang, J., Tang, F., Zheng, A., Cheng, X., Wen, H., 2008. High-resolution sequence stratigraphy analysis of Xiagou Formation, Lower Cretaceous in Qingxi Sag, Jiuquan Basin. Acta Sedimentologica Sinica 26, 624-631 (in Chinese, English abstract).

Wang, Q.M., Coward, M.P., 1993. The Jiuxi Basin, Hexi Corridor, NW China - Foreland structural features and hydrocarbon potential. Journal of Petroleum Geology 16, 169-182.

Wen, H., Zheng, R., Geng, W., Fan, M., Wang, M., 2007. Characteristics of rare earth elements of lacustrine exhalative rock in the Xiagou Formation of Lower Cretaceous in Qingxi sag, Jiuxi basin. Frontiers of Earth Science in China 1, 333-340.

Wu, C.Q., 1983. Jiuquan Basin - a highly explored (mature) area and its exploration future. AAPG Bulletin 67.

Xiao, A., Chen, Z., Yang, S., Ma, L., Gong, Q., Chen, Y., 2005. The study of late Cretaceous paleostructural characteristics in northern Qaidam Basin. Earth Science Frontier 12, 451-457 (in Chinese, English abstract).

Yang, S., Chen, H., Xiao, A., Cheng, X., He, G., Wang, B., 2002. Structural features and their oil controlled action in the Jiuquan Basin. Unpublished report. Department of Earth Sciences, Zhejiang University (in Chinese).

Zhao, X., Xia, Y., Pan, L., Xie, J., 2004. Structural character of frontland thrust belt of Jiuquan Basin South Margin and oil/gas exploration direction. Oil Geophysical Prospecting 39, 222-227 (in Chinese, English abstract).

Zhao, Y., Dai, J.S., 2003. Identification of growth fault by fault fall analysis. Petroleum Exploration and Development 30, 13-15 (in Chinese, English abstract).

Zhu, L.D., Wang, C.S., Zheng, H.B., Xiang, F., Yi, H.S., Liu, D.Z., 2006. Tectonic and sedimentary evolution of basins in the northeast of Qinghai-Tibet Plateau and their implication for the northward growth of the plateau. Palaeogeography, Palaeoclimatology and Palaeoecology 241, 49-60. 